\title{
The Propensity And Intensity Of Export Activities Of Companies Operating In Europe
}

João Pedro Almeida Couto, University of the Azores, Portugal Maria Teresa Borges Tiago, University of the Azores, Portugal José Cabral Vieira, University of the Azores, Portugal Francisco José Ferreira Silva, University of the Azores, Portugal

\begin{abstract}
Previous studies have explored the substantial benefits for companies and governments of exporting. Nevertheless the role of government has been analysed mainly trough export promotion programs and the importance of the subsidiaries of multinational companies to increment a country exports has not been tested together with other variables present in the literature on export performance. This research examines the export performance of companies in Europe. A sample of 239 companies in 12 countries was analysed and their level of exports was examined, using Logit and Tobit models. The contextual variables of the country of operations were combined with company characteristics, including dimension, age, and industry affiliation. The results show that foreign affiliation, age, country of operations and industry are important and that government efficiency is a key element to companies' propensity and intensity of export.
\end{abstract}

Keywords: Export performance, marketing, strategy, subsidiaries, multinationals

\section{INTRODUCTION}

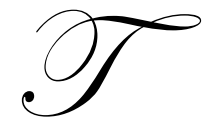

he increasing integration of world markets and the interdependence of resources, products, and services have resulted in the expansion of international trade (World Trade Organization, 2003). Exporting has been the most popular approach adopted by firms in their efforts to enter new markets, since exporting requires less investment and thus less risk (Leonidou et al, 2002).

Export activity has been used as a mean of firm expansion, but also as an important element for economic prosperity and development. Developing and implementing a successful export marketing strategy has been the focus of the public policy makers and research academics due to it's importance to economic activity (Katsikeas, 2003).

This matter has been a topic for research for the last 40 years, in an attempt to establish a conceptual framework that aggregates different streams of literature and empirical study. According to Balanis et al. (2004), these efforts can be found in diverse approaches: export stimulation (Leonidou, 1995a), export barriers (Leonidou, 1995b), the export development process (Leonidou \& Katsikeas, 1996), and the managerial, firm-specific and marketing strategy determinants of export performance (Aaby \& Slater, 1989; Chetty \& Hamilton, 1993; Katsikeas et al., 2000; Leonidou et al., 1998, 2002; Zou \& Stan, 1998).

The purpose of this paper is to examine the effects described in the literature relative to export activity, but considering the aspects of belonging to a multinational network, dimension, age and location, namely the influence of local government efficiency. 
The paper is organized as follows. The next Section 2 sets the theoretical framework of subsidiaries and export activity. Section 3 describes the study propositions. Section 4 presents the data used in this study. Section 4 explains the methodology and the results of the study are presented in section 5. Discussion and conclusions are summarized in Section 6.

\section{LITERATURE REVIEW}

The assessment of export performance has long been an issue of interest in the business ans marketing literature, reflecting both a macro policy concern associated with exporting and a micro focus on competitiveness in export markets (Zou et al., 1998).

The manner in which this question has been approached differs considerably between the several studies undertaken. These alternative approaches can be classified on the basis of three criteria: first, whether the study considers exporting and non-exporting firms or only exporting firms; second, whether the purpose of the study is merely descriptive or explanatory; and third, whether external factors, internal factors, or both types of factors are considered.

A number of authors have investigated the differences between exporters and non-exporters and analysed the factors that influence export performance (Burton \& Schlegelmilch, 1987; Cavusgil \& Nevin, 1981; Cristensen et al., 1987; Keng \& Jiuan, 1988). Others measured the success of exporting firms and studied the relation between this measure and the influencing factors (Cooper \& Kleinschmidt, 1985; Kirpalani \& MacIntosh, 1980; Madsen, 1988; McGuinness \& Little, 1981).

Another possible distinction can be made according to the influencing factors that were considered. Most empirical studies evaluate internal factors (Axinn, 1988; Cavusgil, 1984; Cavusgil \& Nevin, 1981; Reid, 1983) or external environmental factors (Becker \& Porter, 1983; Rao, 1990). These two elements appear combined in other studies that try to construct a more global frame of reference (Kirpalani \& MacIntosh, 1980; Madsen, 1988).

Research on firm export activity can be traced back to the work of Tookey (1964), who first attempted to identify factors associated with successful export strategies. Since then, various studies have tried to establish a conceptual framework that captures the different aspects of export performance (Katsikeas, 2000).

These factors can be grouped into three types of variables that range from background aspects, intervening features to outcomes.

The first type of factors regards environmental, organizational and managerial aspects; the second is related to targeting and marketing strategy; and the third regards to measures of export performance (Axinn, 1994; Cavusgill \& Zou, 1994; Holzmüller \& Kasper, 1991).

Within environmental factors, we can identify different aspects in the domestic and foreign markets, the elements that are mainly outside the control of a firm (Aaby \& Slater, 1989). The organizational factors comprise resources and operating elements, such as company size (Christensen, at al., 1987) necessary human resources and research and development (R\&D) (Beamish, et al., 1993; Gomez-Mejia, 1988).

Another aspect in the export behaviour environment is the effect of public policy. The importance of an adequate public policy to help develop exports has been stressed and related in particular to assistance export programs. Many companies are unable or unwilling to pursue export sales because of lack of international experience, limited resources, or other perceived or real obstacles. Export promotion programs are provided by governments, trade associations, and other trade organisations to help firms, especially small and medium-sized firms, to overcome these limitations (Wheler, 1990). The goal of export promotion programs is to enhance export performance by improving a firm's capabilities, resources, and strategies as well as overall competitiveness (Czinkota, 1996; Diamantopoulos et al., 1993; Seringhaus \& Rosson, 1990). 
The idea considered in this paper is that in addition to specific export promotion programs, government efficiency affects export capabilities by influencing a firm's competitiveness. That is to say, even though a government can have well-intended and defined export promotion programs, the actual export activity will be derived from a firm's competitive capabilities in the international markets and are a result of competition levels in the firm's home country and the effect of public policy in the general economy.

\section{HYPOTHESES}

In this paper we put forward four hypotheses regarding the factors that influence the export behaviour of the companies operating in Europe and measure the combined effects of internal and external factors, namely the aspects of belonging to a multinational network, dimension, age and location, namely the influence of government institutions efficiency.

A first aspect we consider is the fact that a company belongs to a multinational network. In this context the role of the subsidiary's manager in developing initiatives, can be a determinant aspect that leads to export activity and has been the focus of several studies that focus the development of subsidiaries activities (Birkinshaw \& Hood, 1998a, 1998b, 1997; Holm \& Pedersen, 2000; Prahalad \& Doz, 1981; Jarillo \& Martinez, 1990; Kogut \& Zander, 1995; Malnight, 1996).

These aspects have been developed, in the studies of subsidiary roles conducted by Bartlett and Ghoshal (1986), Etemad and Dulude (1986), White and Poynter (1984), Bartlett and Ghoshal (1989) and Hedlund (1986) and subsidiary headquarters relationships (Brandt \& Hulbert, 1976; Hedlund, 1981; Otterbeck, 1981; Vernon, 1966).

Their results reinforce the importance of subsidiaries initiatives and especially of obtain mandates to operate in other markets beyond the host country. The main concept used in this paper is that a foreign subsidiary can have higher export propensity and intensity, if the motive for their establishment is based on exploring local resources for a broader purpose of selling or if this mandate is developed over time. The network relations and the level of resources can foster export activity, and it can be in the best interest of subsidiary managers to obtain mandates to serve foreign markets and guarantee their role and importance in the multinational network.

Hypothesis 1 proposes that: export propensity and intensity will be higher in foreign owned companies.

An important perspective to the level of exports of a firm is provided by the resource-based view where the internal aspects of resources and the configuration of operations are considered.

This perspective relates the firm's operations to its capability to generate and sustain competitive advantage based on the set of strategic resources and competences available in the firm (Barney, 1991; Penrose, 1959; Wernerfelt, 1984).

In this paper we don't specifically analyse the tangible and intangible resources of the firm and the influence of those resources on the propensity and level of exports, we do try to account for this aspect by regarding dimension and age as determinants of the level of resources available and the amount of competences accumulated.

Theoretical developments in the resource-based-view (RBV) of the firm (Penrose, 1959; Wernerflet, 1984; Barney, 1991) point to the fact that firm size is one of the indicators of a firm's organisational resource base and an indicator of managerial and financial availability (Dhanaraj \& Beamish, 2003). The dimension is considered an important variable in understanding export behaviour, since larger firms tend to have more resources available to initiate export initiatives. Empirical evidence also confirms that this aspect is important to the firm's involvement in international business and suggests that it can lead to higher levels of export activity by the firm (Calof, 1994).

Hypothesis 2 proposes that: export propensity and intensity will be higher in larger companies 
Schlegelmilch and Crook (1988) considered that there is a relation between the firm's development and export engaging in terms of the Product Life Cycle Theory (Vernon, 1966), and that export involvement could be associated with domestic sales growth. Therefore, a sequence of exploration experience in the local market would drive export activity and expansion to foreign markets. Styles and Ambler (2000) analysed the relationship between intensity, trust, and relationship commitment and combined these aspects with social learning as determinants of export performance. They specifically considered experimental data collection, market knowledge and market commitment as influencing factors and stressed the importance of social learning as one form of experience that can foster export results.

These authors also identified as environment variables export market attractiveness (Madsen, 1989; Naidu \& Prasad, 1994), infrastructure (Green 1982; Michell, 1979), government barriers (McGuinnes \& Little, 1981; Rabino, 1980), and psychic distance (Bilkey \& Tesas, 1977; Johansson \& Vahlne, 1977; Wiederschiem-Paul, et al., 1978).

The stages of internationalization (Johansson \& Vahlne, 1977) were adopted quickly into the export models, providing a dynamic model of export behaviour (Bilkey \& Tesar, 1977; Cavusgil 1976) and emphasising the importance of experimental knowledge.

A firm's age may indeed reveal its stability, its maturity, and the accumulation of knowledge stock needed to undertake initial export activities, and can explain the further expansion of export activities.

Hypothesis 3 proposes that: export propensity and intensity will be higher in older companies.

A critical aspect of a firm's export policy is export planning, which includes internal organization planning, external orientation and implementation (Jeannet \& Hennessey, 1988).

There is a recommendation that export programs should be adapted to a firm's needs, especially when considering SMEs that face higher barriers due to a lack of resources and experience compared to larger firms. Nevertheless assistance programs are still not well known and used by small firms, and they need to be adapted to the different stages of the internationalization process by reducing export pricing constraints by financing exports in a competitive manner to international competitors by securing interest rates, protection against exchange rate fluctuations, tax rebate systems and export assistance (Moini, 1998).

Export promotion can foster export performance, but is it sustainable? Is it promoting real competitive capabilities development, or just covering business risks and financing company profits? Can the competition in the high tech sectors be derived from export promotion programs? Can the industrial sectors be competitive on a cost basis in an innovation and knowledge society? In this research, we test the influence of government efficiency as a determinant of export activity and compare this influence to the general country effect that can be associated with much broader aspects of language, market dimension, and resources.

We consider government efficiency based on the definition of Evans and Racuh (1999) that created a set of five dimensions to measure it. These measures include the stability of government, efficiency of public institutions, the extent of regulatory activity, the effective rule of law and the level of corruption and accountability.

Hypothesis 4 proposes that: export propensity and intensity vary with government's efficiency

Besides the aspects considered in the hypotheses, we use the industry as a control variable. Porter's (1986) analysis is crucial to understanding the multidimensional nature of competitive industry. The concept of industry as a determinant variable to multinational operations can be found in the works of Prahalad and Doz (1987), Bartlett and Ghoshal (1989), Roth and Morrison (1992) and White and Poynter (1984). The importance of industry as a determinant of marketing adaptation can be found in Buzzell (1968). In this sense the underlined differences between industries affect strategy formulation and operations management in various areas, namely in marketing, is a reason why we consider that export performance should be controlled by the industry. 
The export involvement has been related to industry characteristics since competitive and strategic variables in certain industries can promote more export behaviour and international involvement.

One of the main industry drivers for globalization are cost aspects resulting from research and development activities; empirical evidence supports the idea that exports are more probable in more technologically intensive sectors like electronics or telecommunications (Kogut \& Zander, 1993; Verspagen \& Wakelin, 1993).

Zhao and Zou (2002) consider the industry as an element that determines exports and include the aspects of industry concentration together with firm location as contextual factors of export behaviour; the authors then combine them with the firm's specific aspects of size, innovative capacity, and capital intensity.

\section{METHODOLOGY}

We estimated the regression based on a sample of 239 European firms from the 500 biggest companies in Europe and according to a database from the Dun \& Bradstreet database. The countries used in this study are the following United Kingdom ( $n=73)$, Germany $(n=65)$, Netherlands $(n=41)$, France $(n=30)$, Italy $(n=8)$, Sweden $(n=8)$, Spain $(n=7)$, Finland $(n=3)$, Denmark $(n=2)$, Austria $(n=1)$ and Belgium $(n=1)$. Basic descriptive statistics of this sample are presented in the Appendix.

The effectiveness of export sales organization can be broadly defined as a summary index of organizational outcomes that range from export sales volume and market share through foreign customer satisfaction to export profitability. For this study, we considered two definitions: first, measuring the existence of export activity; and second, measuring the level of export activity as represented by the percentage of exports on total sales volume.

In terms of explanatory variables, the foreign affiliation was measured as a dummy variable, represented by a 1 if the companies were foreign subsidiaries and 0 otherwise.

The dimension and age of the company are both continuous variables. Dimension is based on the number of employees, and age is based on the number of years of establishment.

To measure specific influences of government intervention on export behaviour we considered two variables. The first variable used was the level of public expenditures relative to Gross Domestic Product per capita. With this variable, we try to verify the level of public presence in the economy. The second variable evaluated is the efficiency of government institutions and systems and is divided in five measures used by Evans and Rauch (1999). These measures include an evaluation of stability, efficiency, regulatory activity, effective rule of law and level of corruption and accountability.

To test the influence of national effects, we considered in the regression the Netherlands, the United Kingdom, and Germany, taking the remaining countries in the data as a reference. This procedure was used for two reasons: first, because after testing individually the explanatory capability of each country we found that only these countries showed significant influence; and, second, considering the fact that for estimation purpose it is better to include a more reduced number of variables in order to maximize the estimation results. These results are always analysed in these models by testing if the included countries are significantly different from the ones not individually expressed in the model.

For the purposes of constructing the control variable, we subdivided the industry into the following four dummy variables: (1) Automobile and Aerospace; (2) Chemicals and Pharmaceutics (3) Electronics, Utilities and Components; (4) Food and Retail. We considered the remaining industries present in the sample as reference taking the same logic considered in the case of the country selection.

The export behaviour is analysed from two perspectives, namely, propensity and intensity. For this purpose first we used a logit regression model to analyse the propensity of firms to begin export activity, and secondly, we used a tobit regression model to evaluate the intensity of a firm's exports. 
The first model is adopted considering the dichotomous form of the variable that is zero, when there is no export activity, and one, when there is export activity, and uses the full sample of 239 . The second model is suited for this analysis, since the dependent variable is a percentage variable, and considers the level of foreign sales in relation to total sales and is limited, varying between zero and one (0-100\%), and uses only the 100 of the 239 sample of companies with export activity.

The estimation results for the model on export propensity can be found in Table 1, where we have done two regressions: (i) considering the effect of location using the country of operations as an explanatory variable, and (ii) considering the public expenses and government efficiency. The same procedure was also used in evaluating the export intensity.

\section{RESULTS}

When analysing the export propensity we found in the first model estimated, with countries has a measure of external environment, that the variables with significant explanatory power in terms of organizational aspects were the foreign affiliation and the number of years, both with a positive relation to export propensity. The size of the company did not prove to be a significant variable in explaining export initiation.

In terms of external environment aspects, we observed that the firms in the United Kingdom and Germany showed a higher propensity for export activity, in relation to the other countries.

When we analysed the results for the industry, which was the control variable used in the estimations, we found that it is significant in the case of the Automobile industry where we observed a positive relation to export propensity and for the Food and Retail sector, where we observed a negative relation, when compared with the other industries.

In the second model, where we substituted the country by their specific level of public expenses and government efficiency measures, we verified that the level of public expenses was not significant, but the indicators on government efficiency were highly significant. We can see that when government efficiency is introduced, this variable is not only very significant, but also changes the level of significance of other variables that were representative in the first model. That is the case of the number of years of operations of the company, which was first significant and now isn't any more.

\begin{tabular}{|c|c|c|c|c|}
\hline \multirow[t]{2}{*}{ Independent Variables } & \multicolumn{2}{|c|}{ Model 1} & \multicolumn{2}{|c|}{ Model 2} \\
\hline & Coef. & $p>|t|$ & Coef. & $\mathrm{p}>\mathrm{|t|}$ \\
\hline Dimension & 0,000 & 0,955 & 0,000 & 0,911 \\
\hline Foreign & 1,024 & $0,087 * \star$ & 2,034 & $0,010 * *$ \\
\hline Years & 0,006 & $0,068 * *$ & 0,004 & 0,353 \\
\hline Netherlands & $-1,171$ & 0,163 & & \\
\hline United Kingdom & 2,002 & 0,000 * & & \\
\hline Germany & 2,516 & 0,000 * & & \\
\hline Gov. Institutions & & & 5,926 & 0,000 * \\
\hline Public Expenses & & & $-3,909$ & 0,101 \\
\hline Automobile & 1,029 & $0,066 * \star$ & $-1,319$ & 0,220 \\
\hline Electronics & $-0,449$ & 0,383 & $-2,676$ & 0,039 ** \\
\hline Food \& retail & $-1,202$ & $0,016 * *$ & $-0,488$ & 0,457 \\
\hline Services & $-0,298$ & 0,527 & 0,368 & 0,542 \\
\hline Log likelihood & $-63,538$ & & $-114,513$ & \\
\hline Probability (LR Stat) & 0,000 & & 0,000 & \\
\hline Msfadden R-Squared & 0,601 & & 0,280 & \\
\hline Number of Firms & 239 & & 239 & \\
\hline
\end{tabular}

Significant at * 0,$01 ;{ }^{* *} 0,05 ;{ }^{* *} 0,1$

Table 1- Estimation Results on Export Propensity 
We have done the estimation of similar models, but regarding the level or intensity of exports as the dependent variable. The results can be found in Table 2, and we verified that there were not many changes in the explanatory variables.

Considering the first model, that measures the country effect, as a measure of external environment influence, the changes observed include the influence of the foreign affiliation and show a negative sign in this case when before the results showed a positive relation.

Evaluating the country effect, only the firms from the United Kingdom maintained a higher level of exports and Germany firm's don't have anymore a positive relation to exports that is significantly different from the other countries included in this study.

The industry effects are related to the Automobile and Electronics sector that maintains a higher levels of exports then other industries but the Food and Retail industry becomes not significantly different from other industries.

Regarding the second model, when we express the country effects trough public expenses level and measures of government efficiency, we verified that the results were also similar and that foreign capital and government's efficiency, together with the electronic industry, are the significant variables in explaining export intensity.

\begin{tabular}{|c|c|c|c|c|c|c|}
\hline Independent Variables & Moc & & & Moc & & \\
\hline & Coef. & $p>|t|$ & & Coef. & $p>|t|$ & \\
\hline Dimension & 0,000 & 0,417 & & 0,000 & 0,899 & \\
\hline foreign & $-21,077$ & 0,009 & * & $-6,063$ & 0,019 & ** \\
\hline years & 0,113 & 0,035 & $\star \star$ & $-0,006$ & 0,732 & \\
\hline Netherlands & 27,085 & 0,169 & & & & \\
\hline United Kingdom & 18,147 & 0,029 & $\star \star$ & & & \\
\hline Germany & 2,717 & 0,737 & & & & \\
\hline expscale & & & & 25,305 & 0,000 & * \\
\hline publicexp & & & & 19,372 & 0,080 & ** \\
\hline automobile & 12,880 & 0,078 & $\star \star \star$ & $-3,525$ & 0,127 & \\
\hline electronics & 17,732 & 0,023 & $\star *$ & 1,027 & 0,677 & ** \\
\hline food \& retail & $-12,978$ & 0,120 & & $-3,563$ & 0,172 & \\
\hline services & $-6,664$ & 0,390 & & $-0,373$ & 0,875 & \\
\hline Censored Observations & 139 & & & 139 & & \\
\hline Number of Firms & 100 & & & 100 & & \\
\hline
\end{tabular}

Significant at ${ }^{*} 0,01 ;{ }^{* \star} 0,05 ;{ }^{* \star *} 0,1 \quad$ Table 2- Estimation Results on Export Intensity

A first aspect of these results is that export propensity factors and export intensity factors are similar. The main differences observed are related to foreign affiliation. In this case, although it tends to promote export activity, national companies export more intensely.

A second relevant aspect of these results is that government efficiency emerges as a very significant variable, more so than the level of public expenses. In fact, this variable alone explains a large portion of the dependent variables and eliminates the explanatory significance of other variables. 
A third aspect is that both operation and contextual aspects are significant in explaining export propensity and intensity. The location factor is relevant, and this aspect can be seen in all models namely when we consider the case of the United Kingdom. Industry aspects are also relevant in all models.

\section{DISCUSSION AND CONCLUSIONS}

In this paper we examined the factors that influence export propensity and export intensity. The results show that export propensity and intensity are influenced by operational and contextual factors and do vary by industry. More significantly, we establish that government efficiency can be associated with a higher level of companies' exports.

Considering the hypotheses formulated we verify that there is a significant relationship between export propensity and intensity with foreign affiliation of companies and with a higher number of years of establishment. However, we could not confirm a significant relationship with company size.

This result supports Hypothesis 1 partially, in which we established a positive relationship between export activity and foreign affiliation. In fact, we found a significant positive relationship with export propensity, but a negative relationship with export intensity.

What this result shows is that foreign affiliation can be a factor that promotes export activity engagement, however when we consider all the companies that have export activity, foreign affiliated companies have a lower level of exports.

Considering that there are different reasons for foreign direct investments that include serving local markets or exploring local knowledge, we can understand that subsidiaries, although tend to have export activity are not always oriented specifically to export.

Contrarily to what we expected subsidiary size does not have a significant influence on the presence or level of exports. Yet this result can be associated with the fact that we selected the companies for this study from the 500 largest companies in Europe. This characteristic of selection may indicate that the specific nature of the sample alone is determining the results obtained, and that other sample procedures could prove otherwise. Nevertheless these results led us to reject Hypothesis 2.

The results obtained from the study show a positive relation of export propensity and intensity to the age of the company. This confirms Hypothesis 3 and suggests that there is, in general, the need to have some maturation and organizational development to engage in export activity. Nevertheless we must stress that companies in certain conditions and industries can engage in export activities early on, or right from their creation.

The aspects of public expense and institutions efficiency were addressed with special attention. The results show no significant differences in terms of export activity due to public expenses, but did show high significance regarding government efficiency.

We have to consider that the variables used to measure government efficiency are aggregate indices of different dimensions. These dimensions refer to different and broad aspects that go from the general efficiency of institutions and public systems to the level of regulatory activity and the application of rule of law and to the questions of accountability corruption and stability.

Although these measures were developed for a larger number of countries and used to explain the level of development, they have proven to be relevant in the more closely universe of European countries where differences in development levels and government organization are not as different as in broader contexts.

The national effects due to company location proved to be significant and especially relevant in the case of the United Kingdom. This result can be related not only to specific national effects, but also to the high degree of 
presence of companies with foreign affiliations in this country. It confirms Hypothesis 4 and reinforces the importance of public activity in developing the economic and in this case export activity.

The results obtained confirm the importance of the industry as a relevant variable to consider when analysing export activity since the research verified that this activity can vary significantly from one sector to the other, due to the nature of the business organization and the technology.

The results permit us to consider that the objectives of this study were obtained and that the study contributes to establish that export activity is positively associated with internal factors, such as foreign affiliation or age of the company and contextual factors, such as the efficiency of governmental institutions. Nevertheless, we found no relationship between size and export activity, which contradicts previous results and may be due to the nature of the sample used in this study of large companies.

Further, we conclude that export activity is related to foreign affiliation, but has a different relationship then predicted and suggests an aspect that should be further tested.

For managers, the results show that a firm's business environment is relevant to companies' operations when undertaking export activities, especially government efficiency, which is positively related to higher export levels. This result can be due to various aspects that need to be further investigated, but may be associated to less bureaucratic processes that promote easier business operations, conflict resolution, and better protection of intellectual rights and fosters research and development initiatives. Export activity elevates the level of competition that a company faces, and the factors that distort competition become a burden to business initiatives in international markets.

The need for organization development and maturation is also an aspect that was proven in this study to be associated to export activity. Managers have to consider such factors when they set their business goals.

A limitation of this work is the geographical scope that is shortcoming when considering the generalization of the conclusions. This work could benefit from an enlarged sample that includes other companies outside Europe. Other future research should focus in a more in-depth analysis of export activity and government efficiency.

\section{ACKNOWLEDGEMENTS}

FCT - CEEApla, Research Center of the Atlantic for Applied Economics

\section{REFERENCES}

1. Aaby, Nils-Erik and Stanley F. Slater, "Management Influences on Export Performance: A Review of the Empirical Literature 1978- 1988," International Marketing Review, vol. 6, no.4 (1989), pp.7-26.

2. Axinn, Catherine N, "Export performance: Do managerial perceptions make a difference?," International Marketing Review, vol. 5, no. 2 (Summer) (1988), pp. 61-71.

3. Axinn, Catherine N., Ron Savitt, James M. Sinkula, and Sharon V. Thach, "Export Intention, Beliefs, and Behaviors in Smaller Industrial Firms," Journal of Business Research, vol. 32 (1994), pp. 49-55.

4. Barney, Jay B., "Firm resources and sustained competitive advantage," Journal of Management, vol. 17 (1991), pp. 99-120.

5. Bartlett, Christopher A. and Sumantra Ghoshal, "Tap your subsidiaries for global reach," Harvard Business Review, vol. 64, no.6 (1986), pp. 87-94.

6. Bartlett, Christopher A. and Sumantra Ghoshal, "Managing across borders: The transnational solution," Harvard Business School Press, Boston, MA, Chapter 1 (1989) (also a Sloan Management Review article from Summer, 1987, pp. 7-17)

7. Beamish, Paul W., Ron Craig, and Kerry McLellan, "The performance characteristics of Canadian versus UK exporters in small and medium-sized firms," Management International Review, vol. 13, no.2 (1993), pp. 12137. 
8. Becker, T. H. and J.L. Porter, " Small business plus export trading companies: new formula for export success?," Small Business Management, vol. 21, (October, 1983), pp. 8-16.

9. Bilkey, Warren J. and George Tesar, "The export behaviour of smaller-sized Wisconsin manufacturing firms," Journal of International Business Studies, vol. 8, no.1 (1997), pp. 93-8.

10. Birkinshaw, Julian and Neel Hood, "An empirical study of development processes in foreign-owned subsidiaries in Canada and Scotlandm," Management International Review, vol. 37, no.4 (1997), pp. 339-364.

11. "Multinational subsidiary evolution: capability and charter change in

12. foreign-owned subsidiary companies", The Academy of Management Review, vol. 23, no. 4 (1998a), pp.773-95. , "Multinational corporate evolution and subsidiary development," Houndmills: Macmillan (1998b), pp. 268-298.

13. Brandt, William K. and James M. Hulbert, "Patterns of communications in the multinational corporation: an empirical study," Journal of International Business Studies, vol. 7, no. 1 (1976), pp. 57-64.

14. Burton, F. N. and Bodo B. Schlegelmilch, "Profile Analyses of Non-Exporters Versus Exporters Grouped by Export Involvement," Management International Review, vol. 27, no.1 (1987), pp. 38-49.

15. Buzzell, Robert D., "Can you standardize multinational marketing?," Harvard Business Review, vol. 46, (November-December, 1968), pp. 102-113.

16. Calof, Jonathan L. (1994), “The relationship between firm size and export behaviour revisited," Journal of International Business Studies, vol. 25, no. 20 (1994), pp. 367-387.

17. Cavusgil, S. Tamer. And J.R. Nevin, "State-of-the-art in international marketing: An assessment," (1981) in Enis, B. M. and Roering, H.J. (Eds.), Review of Marketing, American Marketing Association, Chicago, Illinois, pp. 195-216.

18. $\quad$ and Shaoming Zou, "Marketing Strategy - Performance Relationship: An Investigation of the Empirical Link in Export Market Ventures," Journal of Marketing, vol. 58, (January, 1994), pp. 1- 21.

19. _ "Organizational characteristics associated with export activity," Journal of Management Studies, vol. 21, no. 1(1984), pp.3-22.

20. Chetty, Sylvie K. and R.T. Hamilton, "Firm-level determinants of export performance: a meta analysis," International Marketing Review, vol. 10 (1993), pp.26-34.

21. Christensen, Carl. H., Angela da Rocha and Rosane Kerbel Gertner, "An Empirical Investigation of the Factors Influencing Exporting Success of Brazilian Firms," Journal of International Business Studies, vol. 18, no. 3 (Autumn, 1987), pp. 61-77.

22. Cooper, Robert G and Elko J Kleinschmidt, "The Impact of Export Strategy on Export Sales Performance," Journal of International Business Studies, vol. 16, no. 20 (Spring, 1985), pp. 37-55.

23. Czinkota, Michael R., "Why national export promotions?", International Trade Forum, vol. 2 (1996), pp. 1023, 28.

24. Dhanaraj, Charles and Paul W Beamish, "A Resource-Based Approach to the Study of Export Performance," Journal of Small Business Management, vol. 41, no.3 (2003), pp. 242-61.

25. Diamantopoulos, Adamantios, Bodo B.Schlegelmilch and Karen Inglis, "Evaluation of export promotion measures: a survey of Scottish food and drink exporters", (1991), In Seringhaus, F.H.R. and Rosson, P. (Eds), Export Development and Promotion: Tim Rule of Public Organizations, Kluwer Academic Publishers, Norwall, MA, pp. 189-216.

26. Etemad, Hamid and Louise Seguin Dulude, Managing the multinational subsidiary, (1986), Croom Helm: London.

27. Evans, Peter and James E. Rauch, "Bureaucracy and growth: A cross-national analysis of the effects of Weberian state structures on economic growth," American Sociological Review, vol. 64, no. 5 (1999), pp. 748765 .

28. Gomez-Mejia, Luís R., "The role of human resources strategy in export performance," Strategic Management Journal, vol. 9, no.5 (1988), pp. 493-505.

29. Green, C. H. "Effective marketing planning for exporting to the United States," (1982), In Michael R. Czinkota and George Tesar (Eds), Export Management: An International Context, New York: Praeger.

30. Hedlund, Gunnar, "Autonomy of subsidiaries and formalization of headquarters-subsidiary relationships in Swedish MNC's,” (1981), In L. Otterbeck, (Ed), The Management of Headquarters-Subsidiary Relationships in Multinational Corporations, Aldershot, Hants, U.K: Gower. 
31. _The Hypermodern MNC: a Heterarchy?," Human Resource Management, vol. 25, no. 1 (1986), pp.9-35.

32. Holm, Ulf and Torbem Pedersen, "The emergence and impact of MNC centers of excellence: A subsidiary perspective," (2000), Basingstoke: Macmillan.

33. Holzmüller, Hartmut H. and Helmut Kasper, "On a theory of export performance: Personal and organizational determinants of export trade activities observed in small and medium-sized firms," Management International Review, vol. 31, (Special Issue, 1991), pp. 45-70.

34. Jarillo, J. Carlos and Jon I. Martínez, "Different roles for subsidiaries: The case of multinational corporations in Spain," Strategic Management Journal, vol. 11 (1990), pp.501-512.

35. Jeannet, Jean-Pierre and David H. Hennessey, "International marketing management," (1989), Boston, Houghton Mifflin.

36. Johansson, Jan and Jan-Erik Vahlne, "The internationalization process of the firm: A model of knowledge development and increasing foreign markets commitment," Journal of International Business Studies, vol. 8, no.1 (1997), pp.23-32.

37. Katsikeas, Constantine S. “Advances in international marketing: Theory and practice," International Business Review, vol. 12, no. 2 (2003), pp.135-40.

$38 . \quad$, Leonidas C Leonidou, and Neil A Morgan, "Firm-level Export Performance Assessment: Review, Evaluation, and Development," Journal of the Academy of Marketing Science, vol. 28, no.4 (2000), pp. 493-511.

39. Keng, Kau Ah and Tan Soo Jiuan, "Difference between small and medium size exporting and non-exporting firms," (1988) In Micahel R. Czinkota and G. Tezar. (Eds.), Export Management: An international context, New York, Praeger, pp. 27-40.

40. Kirpalani, V. H., Manek and N.B. MacIntosh, "International Marketing effectiveness of technology-oriented small firms," Journal of International Business Studies, Vol. 11, No. 3 (Winter, 1980), pp. 81-90.

41. Kogut, Bruce and Udo Zander, "Knowledge of the firm and the evolutionary selection: Interrelated processes of change," Organisation Science, vol. 2 (1993), pp. 140-145.

42. , "Knowledge, market failure and the multinational enterprise: A reply," Journal of International Business Studies, vol. 26, no.2 (1995), pp. 417-427.

43. Leonidou, Leonidas C., "Export stimulation research: Review, evaluation, and integration," International Business Review, vol. 4, no.2 (1995a), pp.133-56.

$44 . \quad$. "Empirical research on export barriers: Review, assessment and synthesis," Journal of International Marketing, vol. 3, no.1 (1995b), pp. 29-43.

45. , Constantine S Katsikeas, and Nigel F Piercy, "Identifying Managerial Influences on Exporting: Past Research and Future Directions," Journal of International Marketing, vol. 6, no.2 (1998), pp. 74-102.

46. , Constantine S Katsikeas, and Saeed Samiee, "Marketing Strategy Determinants of Export Performance: A Meta-Analysis," Journal of Business Research, vol. 55, no.1 (2002), pp. 51-67.

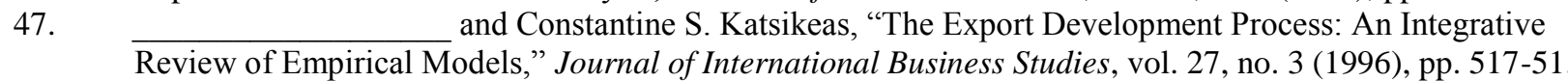

48. Madsen, Tage Koed, "Successful Export Marketing Management: Some Empirical Evidence," International Marketing Review, vol. 6, no. 4 (1989), pp. 41-57.

$49 . \quad$ _Executive Insights: Managerial Judgment of Export Performance," Journal of International Marketing, vol. 6, no.3 (1988), pp. 82-93.

50. Malnight, Thomas. W., "The transition from decentralized to network-based MNC structures: An evolutionary perspective," Journal of International Business Studies, vol. 27, no.1 (1996), pp. 43-65.

51. McGuinness, Norman W and Blair Little, "The Influence of Product Characteristics on the Export Performance of New Industrial Products," Journal of Marketing, vol. 45, (Spring) (1981), pp. 110-22.

52. Michell, P. C. N., "Infrastructure \& international marketing effectiveness," Columbia Journal of World Business, (Spring, 1979), pp.91-101.

53. Moini, Hamid, "Small firms exporting: How effective are government export assistance programs?," Journal of Small Business Management, vol. 36, no. 1 (1998), pp. 1-15.

54. Naidu, G. M. and V. Kanti Prasad, "Predictors of export strategy and performance of small-sized and mediumsized firms," Journal of Business Research, vol. 321, no.1/2(1994), pp. 107-115. 
55. Otterbeck, Lars, "The management of headquarters-subsidiary relations in Multinational corporations," (1981) Hampshire, U.K.: Gower Publishing Co.

56. Penrose, Edith Tilton, "The theory of the growth of the firm," (1959), New York, John Wiley.

57. Porter, Michael, "Competition in global industries", (1986), Boston: Harvard Business School Press.

58. Prahalad, C. K. and Yves L. Doz, "An approach to strategic control in MNC 's," Sloan Management Review, (Summer, 1981), pp. 5-13.

$59 . \quad$ _ "The multinational mission: balancing local demand and global vision," (1987), New York, The Free Press.

60. Rabino, Samuel, "An examination of barriers to exporting encountered by small manufacturing companies," Management International Review, vol. 1 (1980), pp. 67-73.

61. Rao, C. P. "Impact of domestic recession on export marketing behaviour," International Marketing Review, vol. 7, no.2 (1990), pp. 54-65.

62. Reid, Stanley D., "Managerial and firm influences on export behaviour," Journal of the Academy of Marketing Sciences, vol. 11, Summer (1983), pp. 323-332.

63. Roth, Kendall and Allen J. Morrison, "Implementing global strategy: characteristics of global subsidiary mandates," Journal of International Business Studies, vol. 23, no.4 (1992), pp. 715-735.

64. Schlegelmilch, Bodo B. and J.N. Crook, "Firm-level decisions of export intensity," Managerial and Decision Economics, vol. 9, no.4 (1988), pp. 291-300.

65. Seringhaus, F. H. Rolf and Philip J. Rosson, “Government export promotion: A global perspective," (1990), Routledge, Lodon.

66. Styles, Chris and Tim Ambler, "The Impact of Relational Variables on Export performance: An Empirical Investigation in Australia and the UK," Australian Journal of Management, vol. 25, no. 3 (2000), pp. 261-81.

67. Tookey, Douglas A., "Factors associated with success in exporting," Journal of Management Studies, vol.1, no.1 (March, 1964), pp. 48-66.

68. Vernon, Raymond, "International investment and international trade in the product life cycle," Quarterly Journal of Economics, vol.80, (May, 1966), pp. 190-207.

69. Verspagen, Bart and Katharine Wakelin, "Trade and technology from a Schumpeterian perspective," International Review of Applied Economics, vol. 11, no.2 (1993), pp.181-194.

70. Wernerfelt, Birger, “A resource-based view of the firm," Strategic Management Journal, vol. 5, no.2 (1984), pp.171-180.

71. White, Roderick E. and Thomas A. Poynter, "Strategies for foreign-owned subsidiaries in Canada," Business Quarterly, vol. 49, (Summer, 1984), pp.59-69.

72. World Trade Organization, "International trade statistics 2003," (2003), available at: http://www.wto.org/english/res_e/statis_e/its2003_e/its03_toc_e.htm [2006, January 21].

73. Zou, Shaoming and Simona Stan, "The Determinants of Export Performance: A Review of the Empirical Literature Between 1987 and 1997," International Marketing Review, vol. 15, no. 5 (1998), pp. 333-56.

74. Zou, Shaoming, Charles R Taylor, and Gregory E Osland, "The EXPERF Scale: A Cross-national Generalized Export Performance Measure," Journal of International Marketing, vol. 6, no. 3 (1998), pp. 37-58.

75. Zhao, Hongxin and Shaoming Zou, "The Impact of Industry Concentration and Firm Location on Export Propensity and Intensity: An Empirical Analysis of Chinese Manufacturing Firms," Journal of International Marketing, Vol.10, no. 1(Spring, 2002), pp. 52-71. 


\section{APPENDIX}

Table A1- Company Dimension

\begin{tabular}{|c|c|c|c|c|}
\hline \multicolumn{5}{|c|}{ ravie A } \\
\hline Employees & Frequency & Percent & Valid Percent & Cumulative Percent \\
\hline$<1000$ & 29 & 12.1 & 12.4 & 12.4 \\
\hline 1001 a 5000 & 22 & 9.2 & 9.4 & 21.8 \\
\hline 5001 a 10000 & 16 & 6.7 & 6.8 & 28.6 \\
\hline 10001 a 50000 & 78 & 32.6 & 33.3 & 62.0 \\
\hline 50001 a 100000 & 47 & 19.7 & 20.1 & 82.1 \\
\hline$>100000$ & 42 & 17.6 & 17.9 & 100 \\
\hline Total & 234 & 97.9 & 100 & \\
\hline System & 5 & 2.1 & & \\
\hline & 239 & 100 & & \\
\hline
\end{tabular}

Table A2- Years since Company Establishment

\begin{tabular}{|c|c|c|c|c|}
\hline Years of Existance & Frequency & Percent & Valid Percent & Cumulative Percent \\
\hline$<25$ & 44 & 18.4 & 18.4 & 18.4 \\
\hline 26 a 50 & 44 & 18.4 & 18.4 & 36.8 \\
\hline 51 a 75 & 40 & 16.7 & 16.7 & 53.6 \\
\hline 76 a 100 & 46 & 19.2 & 19.2 & 72.8 \\
\hline$>100$ & 65 & 27.2 & 27.2 & 100 \\
\hline Total & 239 & 100 & 100 & \\
\hline
\end{tabular}

Table A3- Company Location

\begin{tabular}{|c|c|c|c|c|}
\hline Country of Operations & Frequency & & Valid Percent & Cumulative Percent \\
\hline United Kingdom & 73 & 30.54 & 30.54 & 30.54 \\
\hline Germany & 65 & 27.20 & 27.20 & 57.74 \\
\hline Netherlands & 41 & 17.15 & 17.15 & 74.90 \\
\hline France & 30 & 12.55 & 12.55 & 87.45 \\
\hline Italy & 8 & 3.35 & 3.35 & 90.79 \\
\hline Sweden & 8 & 3.35 & 3.35 & 94.14 \\
\hline Spain & 7 & 2.93 & 2.93 & 97.07 \\
\hline Finland & 3 & 1.26 & 1.26 & 98.33 \\
\hline Denmark & 2 & 0.84 & 0.84 & 99.16 \\
\hline Austria & 1 & 0.42 & 0.42 & 99.58 \\
\hline Belgium & 1 & 0.42 & 0.42 & 100.00 \\
\hline Total & 239 & 100.00 & 100.00 & \\
\hline
\end{tabular}

Table A4- Company Industry

\begin{tabular}{lcrrr} 
Industry & Frequency & Percent & Valid Percent & Cumulative Percent \\
\hline & & & & \\
Automobile \& Aerospace & 28 & 11.72 & 11.72 & 11.72 \\
Chemicls \& Pharmaceuticals & 20 & 8.37 & 8.37 & 20.08 \\
Eletronics, Utilities \& Componnents & 43 & 17.99 & 17.99 & 38.08 \\
Stell \& Construction & 16 & 6.69 & 6.69 & 44.77 \\
Energy \& Oil & 43 & 17.99 & 17.99 & 62.76 \\
Food \& Retail & 41 & 17.15 & 17.15 & 79.92 \\
Services & 48 & 20.08 & 20.08 & 100.00 \\
Total & 239 & 100.00 & 100.00 & \\
\hline
\end{tabular}


NOTES 